\title{
Sistem Pendukung Keputusan Pemilihan Admin Terbaik Menggunakan Metode Simple Additive Weighting Di Kantor CV Sragen
}

\author{
Pribadi Abthal A J S ${ }^{1)}$, Muhammad Hasbi ${ }^{2 *}$, Kumaratih Sandradewi ${ }^{3)}$ \\ 1) Sistem Informasi, STMIK Sinar Nusantara Surakarta \\ 2) Informatika, STMIK Sinar Nusantara Surakarta \\ ${ }^{3)}$ Sistem Informasi-D3, STMIK Sinar Nusantara Surakarta \\ 1) 14400080.pribadi@sinus.ac.id, ${ }^{2)}$ mhasbi@ sinus.ac.id, ${ }^{3)}$ kumaratih@sinus.ac.id
}

\begin{abstract}
This company always works hard to be at the forefront with modern service standards supported by professional Human Resources. Human Resource Management greatly affects employee dedication and performance. In this regard, the Company has not been able to optimize, especially in determining the best administrator (Admin). This is due to the absence of media that can process the best admin's judgment in the office. For this reason, it is necessary to apply the best admin support system using the Simple Additive Weighting (SAW) method. The definition of the Simple Additive Weighting (SAW) method is often also known as the weighted addition method. The basic concept of SAW method is to find the weighted sum of the performance ratings for each alternative on all attributes. The purpose of this research is to find out the best admin every month, seen from the accuracy of work attendance, cooperation, discipline, and order. After the data was collected, HRDs can immediately use the calculation application using SAW method to determine the best admin. The test results obtained data that the best admin in CV office is Al which has a value of 0.94
\end{abstract}

Keywords : Decision Support System, Simple Additive Weighting, pHp, MySQL

\section{PENDAhUluan}

Perusahaan ini mengusung tema merajut ide, kreativitas dan kerja keras yang mana di dalamnya banyak dari kalangan pengusaha muda yang kreatif dan berpengalaman. Satusatunya usaha yang menjangkau komunitas kaum terpelajar, bahkan di segala bidang apapun mulai dari perusahaan menengah sampai yang terbesar. Perusahaan berfokus pada kualitas dan disertai kuantitas yang mengorientasikan pada kepuasan konsumen.

Perusahaan ini telah terbukti menjadi salah satunya yang terdepan di dalam bisnis usaha kuliner, dengan menciptakan brand restoran yang sudah menjadi hits dan sukses dipasaran. Beberapa brand sukses yang telah diluncurkan adalah Solchic, Ayam Geprek Dan Inimie Pedas.

Perusahaan ini selalu bekerja keras untuk menjadi yang terdepan dengan standar pelayanan modern yang di dukung dengan Sumber Daya Manusia yang profesional. Pengelolaan Sumber Daya Manusia sangat berpengaruh pada dedikasi dan kinerja karyawan. Berkaitan dengan hal tersebut Perusahaan belum bisa optimal terutama dalam menentukan admin terbaik.

Pengelola masih mengalami kesulitan dalam pembuatan aplikasi Pemilihan Admin Terbaik, hal ini dikarenakan belum adanya Aplikasi yang dapat memproses data seperti Ketertiban, Kedisiplinan, Absensi, Kerjasama secara cepat, dan masih harus dilakukan secara manual dan cukup menguras waktu. Sehingga hal ini masih cukup menyulitkan tim HRD untuk mendapatkan hasil data yang cepat dan valid untuk menentukan siapakah admin terbaik.

Seperti yang telah dilakukan Sigit dan Permana yaitu untuk mendapatkan suatu keputusan terbaik tentang pemilihan mobil terbaik bagi konsumen. Metode yang digunakan sama yaitu simple additive weighting (Sigit, H. T., \& Permana, 2017) dan Resti menerapkan metode SAW untuk pemilihan cabang toko baru (Resti, 2017). Zulita juga menggunakan 
metode yang digunakan sama yaitu simple additive weighting untuk pengambilan keputusan pemilihan dosen berprestasi (Zulita, 2013), maka solusi untuk menangani permasalahan tersebut adalah dengan pembuatan sistem pendukung keputusan menggunakan metode Simple Additive Weighting. Alasan memilih metode SAW karena metode ini memiliki keunggulan antara lain adalah mudah dimengerti, lebih fleksibel, dapat memecahkan persoalan yang kompleks dan melakukan pembelajaran berdasarkan pengetahuan dan pengalaman manusia dalam memecahkan suatu masalah (Afrisawati, 2018). Metode ini di pilih karena mampu menentukan bobot untuk setiap kriteria, dan dilanjutkan proses perangkingan yang akan menyeleksi alternative terbaik.

Sistem pendukung keputusan pemilihan admin terbaik ini akan dikembangkan dengan menggunakan bahasa pemrograman PHP dan MySQL. Hasil penelitian diharapkan dapat membantu mempermudah pemilihan admin terbaik berdasarkan kriteria yang ditentukan.

\section{TINJAUAN PUSTAKA}

Menurut Kusrini (2007) "Sistem merupakan kumpulan elemen yang saling berkaitan yang bertanggung jawab memproses masukan (input) sehingga menghasilkan keluaran (output)."

Sistem informasi adalah suatu sistem didalam suatu organisasi yang mempertemukan kebutuhan pengolahan transaksi harian yang mendukung fungsi operasi organisasi yang bersifat manajerial dengan kegiatan strategi dari suatu organisasi untuk dapat menyediakan kepada pihak luar tertentu dengan laporanlaporan yang diperlukan. (Sutabri, 2012).

Menurut Sutarman (2012) Sistem informasi adalah Sistem dapat didefinisikan dengan mengumpulkan, memproses, menyimpan, menganalisis, menyebarkan informasi untuk tujuan tertentu. Seperti sistem lainnya, sebuah sistem informasi terdiri atas input (data, instruksi) dan output (laporan, kalkulasi).

Konsep Sistem Pendukung Keputusan ditandai dengan sistem interaktif berbasis komputer yang membantu pengambilan keputusan dengan memanfaatkan data dan model untuk menyelesaikan masalah yang bersifat tidak terstruktur dan semi terstruktur (Turban, 2001).

Hidayat menggunakan metode yang digunakan menggunakan metode simple additive weighting dan membuat sistem untuk pengambilan sebuah keputusan untuk penerima beasiswa murid berprestasi (Hidayat, 2017). Sering juga dikenal dengan istilah metode penjumlahan terbobot. Konsep dasar metode Simple Additive Weight (SAW) adalah mencari penjumlahan terbobot dari rating kinerja pada setiap alternatif pada semua atribut.

Langkah-langkah dalam metode SAW antara lain :

1. Membuat matrik keputusan $\mathrm{Z}$ berukuran $\mathrm{m} x \mathrm{n}$, dimana $\mathrm{m}=$ alternatif yang akan dipilih dan $\mathrm{n}=$ kriteria.

2. Memberikan nilai $x$ setiap alternatif (i) pada setiap kriteria (j) yang sudah ditentukan, dimana $1=1,2, \ldots \mathrm{m}$ dan $\mathrm{j}=1,2, \ldots \mathrm{n}$ pada matriks keputusan $\mathrm{Z}$

3. Memberikan nilai bobot preferensi (W) oleh pengambil keputusan untuk masingmasing kriteria yang sudah ditentukan.

$\mathrm{W}=[\mathrm{W} 1, \mathrm{~W} 2, \mathrm{~W} 3, \ldots . . \mathrm{Wj}]$.

4. Melakukan normalisasi matriks keputusan $\mathrm{Z}$ dengan cara menghitung nilai rating kinerja ternormalisasi $\left(R_{i j}\right)$ dari alternatif $A 1$ pada atribut $C_{j}$. 


$$
\mathrm{R}_{\mathrm{ij}}= \begin{cases}\frac{\mathrm{X}_{\mathrm{ij}}}{\operatorname{Max}\left\{\mathrm{X}_{\mathrm{ij}}\right\}} & \text { jika } \mathrm{j} \text { ialah atribut keuntungan (benefit) } \\ \frac{\operatorname{Min}\left\{\mathrm{X}_{\mathrm{ij}}\right\}}{\mathrm{X}_{\mathrm{ij}}} & \text { jika } \mathrm{j} \text { ialah atribut biaya (cost) }\end{cases}
$$

Dengan ketentuan :

a. Atribut keuntungan (benefit) apabila atribut banyak memberikan keuntungan bagi pengambil keputusan, sedangkan atribut biaya (cost) merupakan atribut yang banyak memberikan pengeluaran jika nilainya semakin besar bagi pengambil keputusan.

b. Apabila berupa atribut keuntungan maka nilai (Xij) dari setiap kolom atribut dibagi dengan nilai (Max $\mathrm{X}_{\mathrm{ij}}$ ) dari tiap kolom, sedangkan untuk atribut biaya, nilai (Min $\mathrm{X}_{\mathrm{ij}}$ ) dari tiap kolom atribut dibagi dengan nilai (Xij) setiap kolom.

5. Hasil dari rating kinerja ternormalisasi $(\mathrm{Rij})$ membentuk matriks Ternormalisasi $\{N\}$

6. Melakukan proses perangkingan dengan cara mengalikan matriks ternormalisasi nilai bobot preferensi (W).

7. Menentukan nilai preferensi untuk setiap alternatif $\left(\mathrm{V}_{\mathrm{i}}\right)$ dengan cara menjumlahkan hasil kali antara matriks ternormalisasi $(\mathrm{N})$ dengan nilai bobot preferensi (W).

$$
V_{i}=\sum_{j=1}^{n} W_{j} R_{i j}
$$

Maka nilai Vi yang lebih besar mengindikasikan bahwa alternatif A1 merupakan alternatif terbaik.

Penelitian yang pernah dilakukan antara lain yang dilakukan oleh Sigit dan Permana yaitu hasil yang diharapkan sama-sama untuk mendapatkan rekomendasi yang tepat berdasarkan kriteria yang telah ditentukan untuk mendapatkan suatu keputusan terbaik tentang pemilihan mobil terbaik bagi konsumen. Metode yang digunakan sama yaitu simple additive weighting (Sigit, H. T., \& Permana, 2017).

Demikian juga penerapan metode SAW untuk pemilihan keputusan yang tepat. Membangun sistem dengan kriteria-kriteria yang ditentukan untuk pemilihan cabang toko baru. Hasil rekomendasi terbaik sangat diperlukan (Resti, 2017).

Merancang sistem pendukung keputusan dan menerapkan metode SAW juga sudah dilakukan yaitu tentang Pemilihan guru Pengajar bidang komputer (Simarmata, J., Limbong, T., \& Aritonang, 2018).

Zulita juga menggunakan metode yang digunakan sama yaitu simple additive weighting. Sama-sama mencari cara pengambilan keputusan yang tepat. Hasil akhir penelitian berupa perankingan untuk pengambilan keputusan pemilihan dosen berprestasi (Zulita, 2013).

\section{METODE PENELITIAN}

\subsection{Metode Pengumpulan Data}

Pengumpulan data dengan wawancara, Observasi, Studi pustaka. Pengumpulan data dan informasi ini dilakukan dengan cara mencari referensi dari catatan, buku, jurnal penelitian yang sudah ada sebelumnya. 


\subsection{Analisis Sistem}

Tahapan ini akan melakukan analisis kebutuhan sistem yang digunakan untuk membangun sebuah alat bantu sistem pendukung keputusan pemilihan Admin terbaik di Kantor CV, menggunakan metode SAW, meliputi data karyawan, data kriteria, nilai bobot kriteria, serta hasil perangkingan.

\subsection{Perancangan Sistem}

Tahap ini akan melakukan perancangan kebutuhan sistem yang akan digunakan untuk membangun sebuah alat bantu sistem pendukung keputusan pemilihan Admin terbaik di kantor CV, dengan menggunakan metode SAW meliputi use case diagram, activity diagram, dan entitas relationship diagram. Melakukan perhitungan dari data yang sudah di terima kemudian mendapatkan hasil yang akan di lakukan perangkingan.

3.4 Implementasi

Aplikasi dibuat menggunakan aplikasi PHP dan MySql .

\subsection{Pengujian Sistem}

Penelitian ini menggunakan pengujian validitas. Uji validitas dengan dilakukan menggunakan data lampau dengan cara disimulasikan menggunakan sistem baru dan hasilnya dibandingkan dengan keputusan real.

\section{HASIL DAN PEMBAHASAN}

4.1 Proses perhitungan secara manual menggunakan metode SAW.

4.1.1. Menentukan alternatif, ditunjukkan pada Tabel 1.

Tabel 1 Tabel Alternatif

\begin{tabular}{|l|l|}
\hline \multicolumn{2}{|l|}{ Alternatif } \\
\hline A1 & Admin 1 \\
\hline A2 & Admin 2 \\
\hline A3 & Admin 3 \\
\hline A4 & Admin 4 \\
\hline A5 & Admin 5 \\
\hline A6 & Admin 6 \\
\hline A7 & Admin 7 \\
\hline A8 & Admin 8 \\
\hline A9 & Admin 9 \\
\hline
\end{tabular}

4.1.2 Membuat nilai presentasi dari setiap kriteria pada Tabel 2.

Tabel 2 Nilai Setiap Kriteria

\begin{tabular}{|l|l|l|}
\hline Hasil Test & \multicolumn{1}{|c|}{ Kategori } & Keterangan \\
\hline C1 & Kertetiban & benefit \\
\hline C2 & Kedisiplinan & benefit \\
\hline C 3 & Absensi & cost \\
\hline C4 & Kerjasama & benefit \\
\hline
\end{tabular}

4.1.3 Memberikan nilai bobot kepentingan dari setiap kriteria yang akan menjadi acuan, jumlah total nilai bobot harus 100. Semakin besar nilai bobot semakin penting, ditunjukkan pada Tabel 3. 
Tabel 3 Penentuan nilai bobot untuk setiap kriteria

\begin{tabular}{|l|l|l|}
\hline Kriteria & Presentase \% & Bobot \\
\hline C1 & 25 & 0,25 \\
\hline C2 & 30 & 0,3 \\
\hline C3 & 10 & 0,1 \\
\hline C4 & 30 & 0,3 \\
\hline
\end{tabular}

4.1.4 Adapun sub kriteria dari kriteria yang dilakukan penulis dalam melakukan pemilihan admin terbaik, dapat di lihat pada Tabel 4

Tabel 4 Sub Kriteria

\begin{tabular}{|c|c|c|c|}
\hline Kriteria & Kode & Kategori & Nilai \\
\hline \multirow{4}{*}{ Ketertiban } & 1 & Sangat Buruk & 1 \\
\hline & 2 & Buruk & 2 \\
\hline & 3 & Baik & 4 \\
\hline & 4 & Sangat Baik & 5 \\
\hline \multirow{4}{*}{ Kedisiplinan } & 1 & Sangat Buruk & 1 \\
\hline & 2 & Buruk & 2 \\
\hline & 3 & Baik & 4 \\
\hline & 4 & Sangat Baik & 5 \\
\hline \multirow{4}{*}{ Absensi } & 1 & 1 & 5 \\
\hline & 2 & 2 & 4 \\
\hline & 3 & 3 & 3 \\
\hline & 4 & $>4$ & 1 \\
\hline \multirow{4}{*}{ Kerjasama } & 1 & Sangat Buruk & 1 \\
\hline & 2 & Buruk & 2 \\
\hline & 3 & Baik & 4 \\
\hline & 4 & Sangat Baik & 5 \\
\hline
\end{tabular}

4.1.5 Data Karyawan Kantor CV ditunjukkan pada Tabel 5.

Tabel 5 Data Calon Penerima Bantuan

\begin{tabular}{|c|c|c|c|c|}
\hline Kode & Ketertiban & Kedisiplinan & Absensi & Kerjasama \\
\hline A1 & 4 & 4 & 5 & 4 \\
\hline A2 & 4 & 2 & 5 & 4 \\
\hline A3 & 4 & 4 & 5 & 4 \\
\hline A4 & 4 & 4 & 5 & 4 \\
\hline A5 & 4 & 2 & 3 & 4 \\
\hline A6 & 4 & 2 & 5 & 4 \\
\hline A7 & 4 & 2 & 5 & 4 \\
\hline A8 & 4 & 4 & 5 & 4 \\
\hline A9 & 4 & 4 & 5 & 4 \\
\hline
\end{tabular}

4.1.6 Membuat matriks keputusan yang dibentuk dari tabel rating kecocokan. struktur keputusan yang digambarkan dalam bentuk matriks perbandingan antar berbagai alternatif keputusan berdasarkan kriteria keputusan yang telah ditetapkan, sebagai berikut : 


$$
R=\left[\begin{array}{llll}
4 & 4 & 5 & 4 \\
4 & 2 & 5 & 4 \\
4 & 4 & 5 & 4 \\
4 & 4 & 5 & 4 \\
4 & 2 & 3 & 4 \\
4 & 2 & 5 & 4 \\
4 & 2 & 5 & 4 \\
4 & 4 & 5 & 4 \\
4 & 4 & 5 & 4
\end{array}\right]
$$

4.1.7 Menentukan penggolongan kriteria ditunjukkan pada Tabel 6. Atribut kriteria terdiri dari benefit atau cost, dimana benefit artinya semakin besar nilainya semakin bagus, sedangkan cost semakin kecil nilainya semakin bagus.

Tabel 6. Penggolongan Kriteria

\begin{tabular}{|l|l|l|}
\hline Kriteria & Benefit & Cost \\
\hline Ketertiban & $\sqrt{ }$ & \\
\hline Kedisiplinan & $\sqrt{ }$ & \\
\hline Absensi & & $\sqrt{ }$ \\
\hline Kerjasama & $\sqrt{ }$ & \\
\hline
\end{tabular}

4.1.8 Untuk melakukan normalisasi tabel pada tahap analisa, menggunakan persamaan (2)

1) Melakukan normalisasi matriks R. Dimulai dari kriteria ketertiban dengan golongan benefit maka :

$$
\begin{aligned}
& R_{11}=\frac{4}{\operatorname{Max}\{4 ; 4 ; 4 ; 4 ; 4 ; 4 ; 4 ; 4 ; 4\}}=\frac{4}{4}=1 \\
& R_{21}=\frac{4}{\operatorname{Max}\{4 ; 4 ; 4 ; 4 ; 4 ; 4 ; 4 ; 4 ; 4\}}=\frac{4}{4}=1 \\
& R_{31}=\frac{4}{\operatorname{Max}\{4 ; 4 ; 4 ; 4 ; 4 ; 4 ; 4 ; 4 ; 4\}}=\frac{4}{4}=1 \\
& R_{41}=\frac{4}{\operatorname{Max}\{4 ; 4 ; 4 ; 4 ; 4 ; 4 ; 4 ; 4 ; 4\}}=\frac{4}{4}=1 \\
& R_{51}=\frac{4}{\operatorname{Max}\{4 ; 4 ; 4 ; 4 ; 4 ; 4 ; 4 ; 4 ; 4\}}=\frac{4}{4}=1 \\
& R_{61}=\frac{4}{\operatorname{Max}\{4 ; 4 ; 4 ; 4 ; 4 ; 4 ; 4 ; 4 ; 4\}}=\frac{4}{4}=1 \\
& R_{71}=\frac{4}{\operatorname{Max}\{4 ; 4 ; 4 ; 4 ; 4 ; 4 ; 4 ; 4 ; 4\}}=\frac{4}{4}=1
\end{aligned}
$$




$$
\begin{aligned}
& R_{81=\frac{4}{\operatorname{Max}\{4 ; 4 ; 4 ; 4 ; 4 ; 4 ; 4 ; 4 ; 4\}}}=\frac{4}{4}=1 \\
& R_{91=\frac{4}{\operatorname{Max}\{4 ; 4 ; 4 ; 4 ; 4 ; 4 ; 4 ; 4 ; 4\}}=\frac{4}{4}=1}
\end{aligned}
$$

2) Melakukan normalisasi matriks R. Pertama dimulai dari kriteria kedisiplinan dengan golongan benefit maka :

$$
\begin{aligned}
& R_{12}=\frac{4}{\operatorname{Max}\{4 ; 2 ; 4 ; 4 ; 2 ; 2 ; 2 ; 4 ; 4\}}=\frac{4}{4}=1 \\
& R_{22}=\frac{2}{\operatorname{Max}\{4 ; 2 ; 4 ; 4 ; 2 ; 2 ; 2 ; 4 ; 4\}}=\frac{2}{4}=0,5 \\
& R_{32}=\frac{4}{\operatorname{Max}\{4 ; 2 ; 4 ; 4 ; 2 ; 2 ; 2 ; 4 ; 4\}}=\frac{4}{4}=1 \\
& R_{42}=\frac{4}{\operatorname{Max}\{4 ; 2 ; 4 ; 4 ; 2 ; 2 ; 2 ; 4 ; 4\}}=\frac{4}{4}=1 \\
& R_{52}=\frac{2}{\operatorname{Max}\{4 ; 2 ; 4 ; 4 ; 2 ; 2 ; 2 ; 4 ; 4\}}=\frac{2}{4}=0,5 \\
& R_{62}=\frac{2}{\operatorname{Max}\{4 ; 2 ; 4 ; 4 ; 2 ; 2 ; 2 ; 4 ; 4\}}=\frac{2}{4}=0,5 \\
& R_{82}=\frac{4}{\operatorname{Max}\{4 ; 2 ; 4 ; 4 ; 2 ; 2 ; 2 ; 4 ; 4\}}=\frac{4}{4}=1 \\
& R_{72}=\frac{2}{\operatorname{Max}\{4 ; 2 ; 4 ; 4 ; 2 ; 2 ; 2 ; 4 ; 4\}}=\frac{2}{4}=0,5
\end{aligned}
$$

3) Melakukan normalisasi matriks R. Dimulai dari kriteria absensi dengan golongan cost maka :

$$
\begin{aligned}
& R_{13}=\frac{\operatorname{Min}\{5 ; 5 ; 5 ; 5 ; 3 ; 5 ; 5 ; 5 ; 5\}}{5}=\frac{3}{5}=0,6 \\
& R_{23}=\frac{\operatorname{Min}\{5 ; 5 ; 5 ; 5 ; 3 ; 5 ; 5 ; 5 ; 5\}}{5}=\frac{3}{5}=0,6
\end{aligned}
$$




$$
\begin{aligned}
& R_{33}=\frac{\operatorname{Min}\{5 ; 5 ; 5 ; 5 ; 3 ; 5 ; 5 ; 5 ; 5\}}{5}=\frac{3}{5}=0,6 \\
& R_{43}=\frac{\operatorname{Min}\{5 ; 5 ; 5 ; 5 ; 3 ; 5 ; 5 ; 5 ; 5\}}{5}=\frac{3}{5}=0,6 \\
& R_{53}=\frac{\operatorname{Min}\{5 ; 5 ; 5 ; 5 ; 3 ; 5 ; 5 ; 5 ; 5\}}{3}=\frac{3}{5}=1 \\
& R_{63}=\frac{\operatorname{Min}\{5 ; 5 ; 5 ; 5 ; 3 ; 5 ; 5 ; 5 ; 5\}}{5}=\frac{3}{3}=0,6 \\
& R_{73}=\frac{\operatorname{Min}\{5 ; 5 ; 5 ; 5 ; 3 ; 5 ; 5 ; 5 ; 5\}}{5}=\frac{3}{5}=0,6 \\
& R_{83}=\frac{\operatorname{Min}\{5 ; 5 ; 5 ; 5 ; 3 ; 5 ; 5 ; 5 ; 5\}}{5}=\frac{3}{5}=0,6 \\
& R_{93}=\frac{\operatorname{Min}\{5 ; 5 ; 5 ; 5 ; 3 ; 5 ; 5 ; 5 ; 5\}}{5}=\frac{3}{5}=0,6
\end{aligned}
$$

4) Melakukan normalisasi matriks R. Dimulai dari kriteria kerjasama dengan golongan benefit maka :

$$
\begin{aligned}
& R_{14}=\frac{4}{\operatorname{Max}\{4 ; 4 ; 4 ; 4 ; 4 ; 4 ; 4 ; 4 ; 4\}}=\frac{4}{4}=1 \\
& R_{14}=\frac{4}{\operatorname{Max}\{4 ; 4 ; 4 ; 4 ; 4 ; 4 ; 4 ; 4 ; 4\}}=\frac{4}{4}=1 \\
& R_{14}=\frac{4}{\operatorname{Max}\{4 ; 4 ; 4 ; 4 ; 4 ; 4 ; 4 ; 4 ; 4\}}=\frac{4}{4}=1 \\
& R_{14}=\frac{4}{\operatorname{Max}\{4 ; 4 ; 4 ; 4 ; 4 ; 4 ; 4 ; 4 ; 4\}}=\frac{4}{4}=1 \\
& R_{14}=\frac{4}{\operatorname{Max}\{4 ; 4 ; 4 ; 4 ; 4 ; 4 ; 4 ; 4 ; 4\}}=\frac{4}{4}=1 \\
& R_{14}=\frac{4}{\operatorname{Max}\{4 ; 4 ; 4 ; 4 ; 4 ; 4 ; 4 ; 4 ; 4\}}=\frac{4}{4}=1
\end{aligned}
$$




$$
\begin{aligned}
& R_{14}=\frac{4}{\operatorname{Max}\{4 ; 4 ; 4 ; 4 ; 4 ; 4 ; 4 ; 4 ; 4\}}=\frac{4}{4}=1 \\
& R_{14}=\frac{4}{\operatorname{Max}\{4 ; 4 ; 4 ; 4 ; 4 ; 4 ; 4 ; 4 ; 4\}}=\frac{4}{4}=1 \\
& R_{14}=\frac{4}{\operatorname{Max}\{4 ; 4 ; 4 ; 4 ; 4 ; 4 ; 4 ; 4 ; 4\}}=\frac{4}{4}=1
\end{aligned}
$$

4.1.9 Setelah membuat normalisasi maka langkah berikutnya adalah membuat matrix (R) sebagai berikut :

$$
R=\left[\begin{array}{cccc}
1 & 1 & 0,6 & 1 \\
1 & 0,5 & 0,6 & 1 \\
1 & 1 & 0,6 & 1 \\
1 & 1 & 0,6 & 1 \\
1 & 0,5 & 1 & 1 \\
1 & 0,5 & 0,6 & 1 \\
1 & 0,5 & 0,6 & 1 \\
1 & 1 & 0,6 & 1 \\
1 & 1 & 0,6 & 1
\end{array}\right]
$$

4.1.10 Selanjutnya proses pencarian rangking atau nilai terbaik dengan memasukkan setiap kriteria dan nilai bobot yang digunakan dalam perangkingan ini yaitu $\mathrm{W}=[$ 0,25 0,3 0,15 0,3 ] (Tabel 3) maka proses perangkingan adalah (Rumus (2)):

$$
\begin{aligned}
& \mathrm{V}_{1}=(1)(0,25)+(1)(0,3)+(0,6)(0,15)+(1)(0,3)=0,94 \\
& \mathrm{~V}_{2}=(1)(0,25)+(0,5)(0,3)+(0,6)(0,15)+(1)(0,3)=0,79 \\
& \mathrm{~V}_{3}=(1)(0,25)+(1)(0,3)+(0,6)(0,15)+(1)(0,3)=0,94 \\
& \mathrm{~V}_{4}=(1)(0,25)+(1)(0,3)+(0,6)(0,15)+(1)(0,3)=0,94 \\
& \mathrm{~V}_{5}=(1)(0,25)+(0,5)(0,3)+(1)(0,15)+(1)(0,3)=0,85 \\
& \mathrm{~V}_{6}=(1)(0,25)+(0,5)(0,3)+(0,6)(0,15)+(1)(0,3)=0,79 \\
& \mathrm{~V}_{7}=(1)(0,25)+(0,5)(0,3)+(0,6)(0,15)+(1)(0,3)=0,79 \\
& \mathrm{~V}_{8}=(1)(0,25)+(1)(0,3)+(0,6)(0,15)+(1)(0,3)=0,94 \\
& \mathrm{~V}_{9}=(1)(0,25)+(1)(0,3)+(0,6)(0,15)+(1)(0,3)=0,94
\end{aligned}
$$

Perangkingan nilai $\mathrm{V}$ terbesar ke nilai $\mathrm{V}$ terkecil, dimana nilai $\mathrm{V}$ terbesar adalah nilai terbaik ditunjukkan pada Tabel 7.

Tabel 7 Hasil Perangkingan nilai terbesar ke nilai terkecil

\begin{tabular}{|c|c|}
\hline Kode & Hasil Perangkingan \\
\hline A1 & 0,94 \\
\hline A3 & 0,94 \\
\hline A4 & 0,94 \\
\hline A8 & 0,94 \\
\hline A9 & 0,94 \\
\hline A5 & 0,85 \\
\hline A2 & 0,79 \\
\hline A6 & 0,79 \\
\hline A7 & 0,79 \\
\hline
\end{tabular}


Dari hasil perhitungan diatas dapat ditentukan tiga orang admin terbaik Kantor CV hasil dari nilai $\mathrm{V}_{1}-\mathrm{V}_{29}$ dengan nilai di tunjukkan pada Tabel 8:

Tabel 8 Hasil perangkingan tiga teratas

\begin{tabular}{|c|c|}
\hline Kode & $\begin{array}{c}\text { Hasil } \\
\text { Perangkingan }\end{array}$ \\
\hline A1 & 0,94 \\
\hline A3 & 0,94 \\
\hline A4 & 0,94 \\
\hline
\end{tabular}

\subsection{Implementasi}

\subsubsection{Bobot Penilaian}

Halaman ini berisi nama admin perusahaan, hasil rating kecocokan berdasarkan kriteria dan bobotnya, dapat dilihat pada Gambar 1.
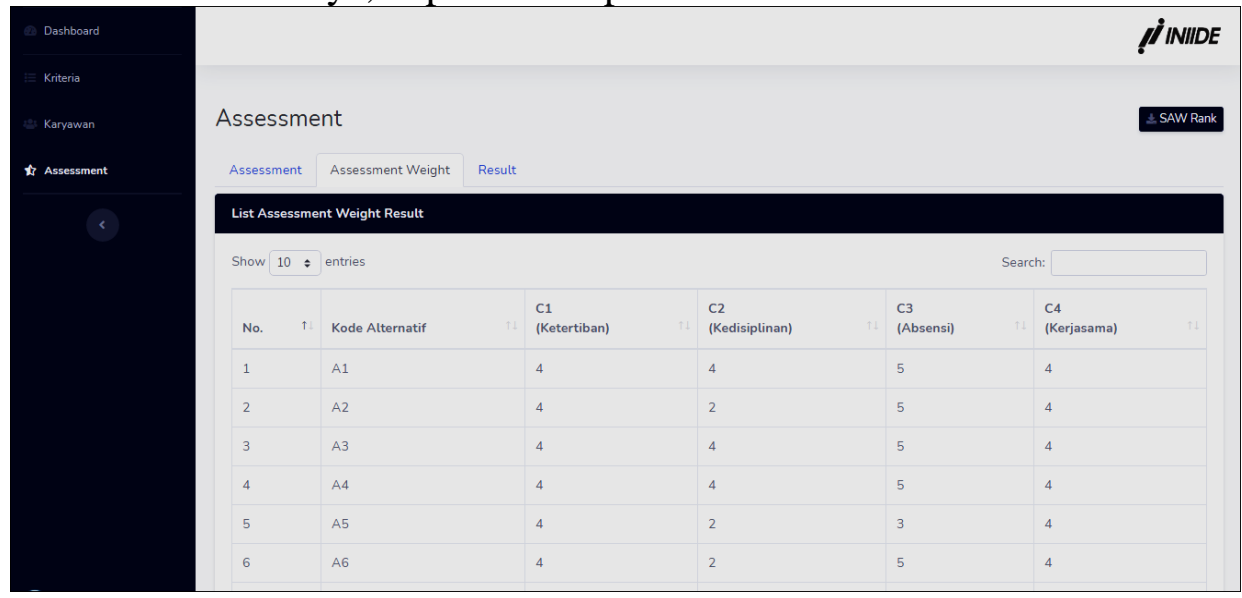

Gambar 1 Bobot Penilaian

4.2.2 Hasil data perangkingan perhitungan menggunkan sistem baru metode Simple Additive Weighting ditunjukkan pada Gambar 2.

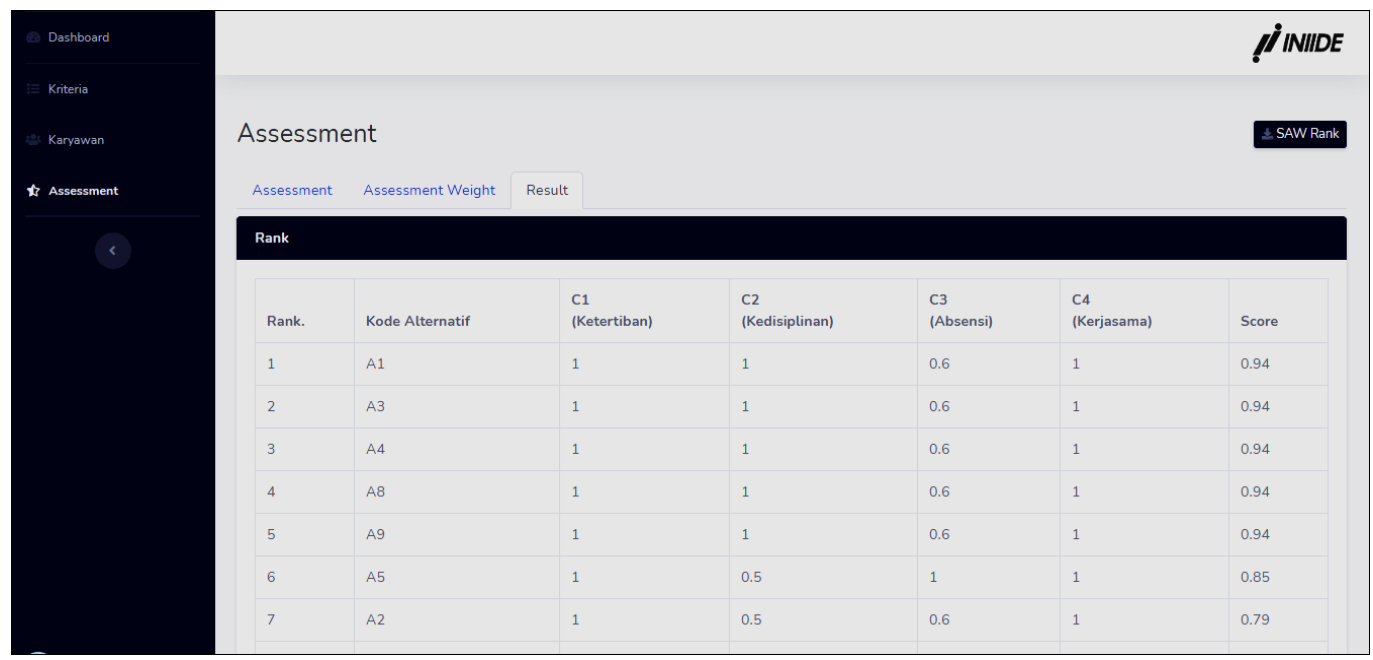

Gambar 2 Hasil perangkingan sistem baru metode SAW 


\subsection{Pengujian Validitas}

Pengujian validitas data digunakan untuk mengetahui perhitungan sistem yang dibuat valid atau tidak. Pengujian validitas data dilakukan dengan membandingkan sistem lama (Tabel 9) dan sistem baru (Gambar 2). Hasil perbandingan menunjukkan nilai yang sama.

Tabel 9 Hasil perangkingan

\begin{tabular}{|c|c|}
\hline Kode & Hasil Perangkingan \\
\hline A1 & 0,94 \\
\hline A3 & 0,94 \\
\hline A4 & 0,94 \\
\hline A8 & 0,94 \\
\hline A9 & 0,94 \\
\hline A5 & 0,85 \\
\hline A2 & 0,79 \\
\hline A6 & 0,79 \\
\hline A7 & 0,79 \\
\hline
\end{tabular}

Berdasarkan pengujian validitas data menggunakan sistem manual dan sistem baru menggunakan metode Simple Additive Weighting menunjukkan bahwa admin terbaik peringkat teratas yaitu A1, A3, A4, A8, A9, A5, A2, A6, A7. Pengujian validitas data tersebut dapat disimpulkan bahwa keakurasian data dengan sistem baru menggunakan metode SAW adalah akurat, karena hasil keputusan perhitungan manual maupun sistem menggunakan metode SAW sama. Dibandingkan dengan Hidayat, R. (2017), pemilihan cabang toko baru hasil rangking 1 mempunyai nilai diatas 0,9. Sedangkan, untuk pemilihan Mobil rangking 1 mempunyai nilai 0,8 (Sigit, H. T., \& Permana), kemudian untuk pemilihan Lokasi untuk Cabang Baru Toko Pakan rangking 1 mempunyai nilai 0,8 (Resti, 2017). Dalam penelitian, hasil yang didapatkan bernilai diatas 0,9 yaitu A1, A3, A4, A8, A9.

\section{KESIMPULAN DAN SARAN}

\subsection{Kesimpulan}

a. Telah dibuat sistem pendukung keputusan pemilihan admin terbaik di Kantor CV Sragen, sebagai alat bantu pengambilan keputusan dalam menentukan siapakah yang akan menjadi admin terbaik dengan metode Simple Additive Weighting. Penggunaan aplikasi yang dibuat akan memudahkan tim HRD untuk mengetahui dan menilai kedisiplinan, ketertiban, absensi dan kerjasama dari admin yang ada di Kantor CV.

b. Aplikasi sistem pemilihan admin terbaik di Kantor CV, memiliki beberapa fitur, diantaranya : mengolah data pengguna aplikasi, mengolah data karyawan, mengolah kriteria dan nilai bobot kriteria karyawan, menampilkan hasil perhitungan nilai bobot kriteria dengan menggunakan metode SAW, dan hasil perangkingan dapat didownload pengguna dalam bentuk pdf file.

c. Hasil perangkingan admin terbaik dari Kantor CV pada peringkat pertama adalah A1, kedua A3, ketiga A4. Dari hasil pengujian tersebut didapatkan data bahwa admin terbaik di kantor CV adalah A1 yang mempunyai nilai 0.94 . 


\subsection{Saran}

Sistem pendukung keputusan pemilihan admin terbaik di kantor $\mathrm{CV}$, dibuat dengan metode SAW untuk memperoleh perangkingan, namun tidak menutup kemungkinan dapat dikembangkan dengan metode lain, misalnya WP (Weighted Product), TOPSIS (Technique for Order Preference by Similarity to Ideal Solution), ataupun AHP (Analytic Hierarchy Process).

\section{DAFTAR PUSTAKA}

Afrisawati. (2018). Sistem Pendukung Keputusan Penerimaan Pegawai Di Stmik Royal Metode Simple Additive Weighting. JURTEKSI (Jurnal Teknologi Dan Sistem Informasi), Vol. $V \quad$ No., https://doi.org/https://doi.org/10.33330/jurteksi.v5i1.294

Hidayat, R. (2017). Metode Simple Additive Weighting Sebagai Sistem Pendukung Keputusan Penerima Beasiswa Murid Berprestasi. 2, 13-17.

Kusrini. (2007). Konsep dan Aplikasi Sistem Pendukung Keputusan. CV Andi Offset.

Resti, N. C. (2017). Penerapan Metode Simple Additive Weighting ( SAW ) pada Sistem Pendukung Keputusan Pemilihan Lokasi untuk Cabang Baru Toko. INTENSIF, 1(2), 102-107.

Sigit, H. T., \& Permana, D. A. (2017). Sistem Pendukung Keputusan Pemilihan Mobil LCGC Menggunakan Simple Additive Weighting.

Simarmata, J., Limbong, T., \& Aritonang, M. (2018). Sistem Pendukung Keputusan Pemilihan Guru Bidang Studi Komputer Menggunakan Metode Simple Additive Weighting ( Saw ). 3(2), 186-190.

Sutabri, T. (2012). Analisis Sistem Informasi. Andi. Yogyakarta.

Sutarman. (2012). Buku Pengantar Teknologi Informasi. Jakarta Bumi Aksara.

Turban. (2001). Decision Support System and intelligent system (Sistem Pendukung Keputusan dan Sistem Cerdas). Andi, Yogyakarta.

Zulita, L. N. (2013). Sistem Pendukung Keputusan Menggunakan Metode SAW Untuk Penilaian Dosen Berprestasi (Studi Kasus di Universitas Dahasen Bengkulu). Issn 1858 - 2680. Media Infotama, 9(2), 94-117. 